\title{
Accumulation of ash and photosynthetic pigments in the raw material of Astragalus
}

\author{
Oleksandr Bondarchuk *, (1) Olena Vergun, (1) Oksana Shymanska, (1) Valentyna Fishchenko, \\ Dzhamal Rakhmetov
}

M.M. Gryshko National Botanical Garden, National Academy of Sciences of Ukraine, Tymiryazevska str. 1, 01014 Kyiv, Ukraine;* bondbiolog@gmail.com

Received: 08.10.2020 | Accepted: 20.12.2020 | Published: 30.12.2020

\begin{abstract}
Five Astragalus species (A. cicer, A. falcatus, A. galegiformis, A. glycyphyllos, and A. ponticus) grown at the M.M. Gryshko National Botanical Garden of the National Academy of Sciences of Ukraine were investigated. Plant raw material was collected at different ontogenetic stages, including budding, flowering, and fruiting. After that, the content of ash, calcium, phosphorus, nitrogen, and photosynthetic pigments was analyzed and statistically processed.

The content of ash varied from 3.12 to $5.22 \%$, calcium - from 0.31 to $0.91 \%$, phosphorus - from 0.07 to $0.14 \%$, and nitrogen - from 1.93 to $2.48 \%$ depending on the stage of growth. The content of chlorophyll $a$ varied from 0.901 to $2.475 \mathrm{mg} / \mathrm{g}$ FW (fresh weight), chlorophyll $b$ - from 0.190 to $0.676 \mathrm{mg} / \mathrm{g} \mathrm{FW}$, and carotenoids - from 0.496 to $1.129 \mathrm{mg} / \mathrm{g} \mathrm{FW}$.

Thus, the accumulation of ash and its components in the raw material of the investigated species depended on the period of growth and certain species. Content of photosynthetic pigments correlated with the content of phosphorus $(r=0.887-0.999)$ and with plant increment $(r=0.756-0.998)$ for all investigated species. Obtained data can be applied to analyze productivity and during the cultivation of these plants.
\end{abstract}

Keywords: Astragalus, raw material, ash content, photosynthetic pigments, correlation

\section{Introduction}

The genus Astragalus L. (Fabaceae Lindl.) is one of the largest genera of vascular plants with approximately 2500-3000 species. It is distributed mainly in arid and semiarid mountainous regions of the northern hemisphere and South America (Ilçim \& Behçet, 2016). Certain Astragalus species are used in folk medicine as cardiovascular, antihypertensive, diuretic, choleretic remedies (Lysiuk \& Darmohray, 2016). Among the most used parts of the plants are gum and roots (Amiri et al., 2020).
Different biological effects and active compounds were recently investigated for some Astragalus species (Wang et al., 2019; Zheng et al., 2020). Adigüzel et al. (2009) found that methanol and hexane extracts did not express neither antimicrobial nor antifungal effect. However, soon Alrumman et al. (2012) reported the antimicrobial activity of A. atropilosulus (Hochst.) Bunge subsp. abyssinicus (Hochst.) Gillett against Candida spp., Drechslera halides, Fusarium oxysporum, and Pythium ultimum. Some Astragalus species also demonstrate antiinflammatory, analgesic (Shojaii et al., 2013), anticancer 


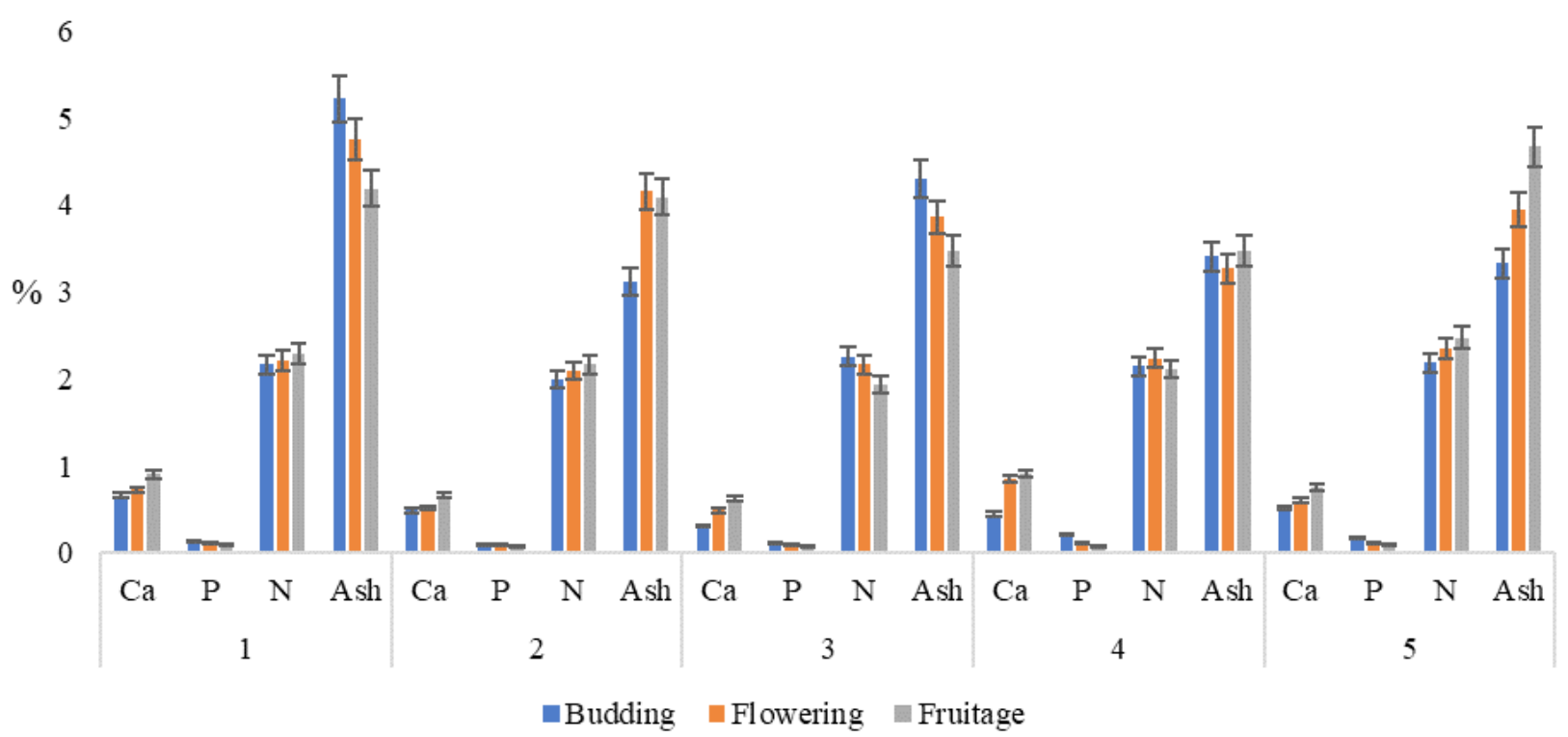

Figure 1. Content of ash and some macroelements in the raw material of Astragalus species: 1 - A. cicer, 2 - A. falcatus, 3 - A. galegiformis, 4 - A. glycyphyllos, 5 - A. ponticus.

(Auyeung et al., 2016), antioxidant (Jaradat et al., 2017; Chasemian-Yadegari et al., 2019), and antidiabetic (Guo et al., 2020) effects. Finally, it was recently reported that flavonoids from different Astragalus species have high antioxidant activity (Berezutskii et al., 2020).

In addition, Astragalus species possess tonic, hepatoprotective, diuretic, antihyperglycemic features (Fu et al., 2014). The strong pharmacological effect and potential immunomodulatory effect of these species appear due to biologically active compounds such as saponins, flavonoids, polysaccharides, phenolic acids, tannins, etc. Astragalus contains 20 trace elements, 20 types of amino acids, and fatty acids (Keskin, \& Kacar, 2013; Zhang, 2013; Fu et al., 2014; Sarraj-Laabidi et al., 2018; Babich et al., 2019; Guo et al., 2019; Li et al., 2019b).

Being the representatives of legume crops, Astragalus plants are an excellent crude protein source, low in fiber. Hence, these plants can compete with other better-known legumes, such as Medicago sativa L. (Asharya et al., 2006).

Many years of investigations at the M.M. Gryshko National Botanical Garden of the National Academy of Sciences of Ukraine (NBG) showed that Astragalus has potential as forage, medicinal, bioenergetics, and ornamental plants. These plants are characterized by high productivity, rich biochemical content, ecological tolerance, and other favorable properties (Bondarchuk, \& Rakhmetov, 2016, 2017; Rakhmetov et al., 2018).

This study aimed to identify peculiarities of certain biochemical parameters of Astragalus species and find the relationship between these parameters during the vegetation period, as well as to evaluate Astragalus species as perspective crops for the ForestSteppe of Ukraine.

\section{Material and methods}

Investigations were conducted in 2012-2018. Plants from the experimental collection of the biochemical laboratory of the Department of the Cultural Flora of the NBG were used. Five Astragalus species (A. cicer L., A. falcatus Lam., A. galegiformis L., A. glycyphyllos L., and A. ponticus Pall.) were investigated during the budding, flowering, and fruiting ontogenetic stages.

The content of ash was determined using the method of combustion in the muffle-oven (SNOL 7,2/1100, Termolab) at $250-500^{\circ} \mathrm{C}$, according to Hrytsajenko et al. (2003). After the combustion procedure, obtained ash was used to determine the content of calcium and phosphorus. The calcium content was determined by acid extracts' titration from obtained ash with Trilon B and given as calcium oxide (Kalnytskyi, 1997). 
The phosphorus content in plants was determined in acid extracts from obtained ash with molybdenum solution, and given as phosphorus oxide (V) (Kalnytskyi, 1997).

The content of nitrogen was determined by the chloramine method (Kalnytskyi, 1997) after the crude ashing procedure (Yermakov et al., 1972).

Photosynthetic pigments were determined spectrophotometrically in the leaves following Musijenko et al. (2001). Briefly, $100 \mathrm{mg}$ of fresh raw material was extracted with a fixed volume of $80 \%$ acetone in the presence of magnesium carbonate. After filtration, the supernatant was used to measure chlorophyll $a($ Chl $a), b(\mathrm{Chl} b)$, and carotenoids content, which was determined at the wavelengths of 662, 644, and $440 \mathrm{~nm}$, respectively. Results were calculated by the Lichtenthaler equation and given in the $\mathrm{mg} / \mathrm{g}$ of fresh weight (FW). Also, obtained data were used to calculate the ratio between photosynthetic pigments.

Three replicates were applied in each treatment. The statistical processing of experimental data was done using the main descriptors: the arithmetic mean, standard deviation, and correlation coefficient. Correlation analysis was conducted using Pearson's criterion.

\section{Results and discussion}

In the previous study, we identified that sugars, protein, ascorbic acid, and cellulose content in five Astragalus species was the highest at the flowering stage (Rakhmetov et al., 2018). The current investigation represent other biochemical parameters determined in Astragalus raw material during the vegetation period, i.e., the content of ash, calcium, phosphorus, nitrogen, and photosynthetic pigments.

The study of ash content in the plants is an important parameter for evaluating the raw material's nutritive quality (Godočiková et al., 2019). The assessment of this parameter also applies to the investigation of energetic crops, wherein found correlation between the content of ash and heating value (Prochnow et al., 2009). In studied Astragalus species, the content of ash varied from 3.12 to $5.22 \%$, depending on species and stage of growth (Fig. 1). The content of calcium, phosphorus, and nitrogen was $0.31-0.91 \%, 0.07-0.14 \%$, and $1.93-2.48 \%$, respectively. The content of phosphorus decreased during vegetation in raw material of all species.

Kumleh et al. (2016) reported that the content of ash in the seed of A. podolobus Boiss. \& Hohen. was $10.42 \%$, which is twothree times higher than our results for raw material from the above-ground parts. A study of another legume, Galega L., showed that ash, phosphorus, and calcium in the raw material is accumulated unevenly, and the content of phosphorus is maximal at the beginning of vegetation (Vergun et al., 2012). In particular, stems of such energetic plants as Miscanthus Andersson had an ash content of 1.38-1.60\%, which is a few times less than those reported by Vergun et al. (2019).

The content of photosynthetic pigments is an essential parameter of plant growth and an indicator of general photosynthetic activity (Lichtenthaler, 1987). It is important to combine investigations of photosynthetic pigments during vegetation with analysis of ecological factors and parameters of growth (Zlatev \& Lidon, 2012). The content of chlorophylls changes with the change of the environmental characteristics, and it is a significant diagnostic indicator of plant growth (Li et al., 2019a).

In this study, we investigated the accumulation of photosynthetic pigments in the leaves of Astragalus species during vegetation. The content of chlorophyll $a$ at the budding stage varied from 2.117 to $2.475 \mathrm{mg} / \mathrm{g}$ FW, chlorophyll $b$ - from 0.445 to $0.676 \mathrm{mg} / \mathrm{g}$ FW, and carotenoids - from 0.995 to 1.129 $\mathrm{mg} / \mathrm{g} \mathrm{FW}$, depending on species (Fig. 2).

At the flowering stage, the content of chlorophyll $a$ varied from 1.329 to $2.111 \mathrm{mg} / \mathrm{g}$ FW, chlorophyll $b$ - from 0.354 to $0.567 \mathrm{mg} / \mathrm{g}$ FW, and carotenoids - from 0.694 to 1.003 mg/g FW (Fig. 3).

At the fruiting stage, chlorophyll $a$ was accumulated in the leaves in the range from 0.901 to $1.913 \mathrm{mg} / \mathrm{g} \mathrm{FW}$, chlorophyll $b$ - in the range from 0.190 to $0.523 \mathrm{mg} / \mathrm{g} \mathrm{FW}$, and carotenoids - from 0.496 to $0.912 \mathrm{mg} / \mathrm{g} \mathrm{FW}$ (Fig. 4).

Stress influences regulatory processes in plants and photosynthetic ability that can be noticed concerning the ratio between carotenoids and the sum of chlorophylls. In this case, the ratio Car / (Chl $a+\mathrm{Chl} b)$ 


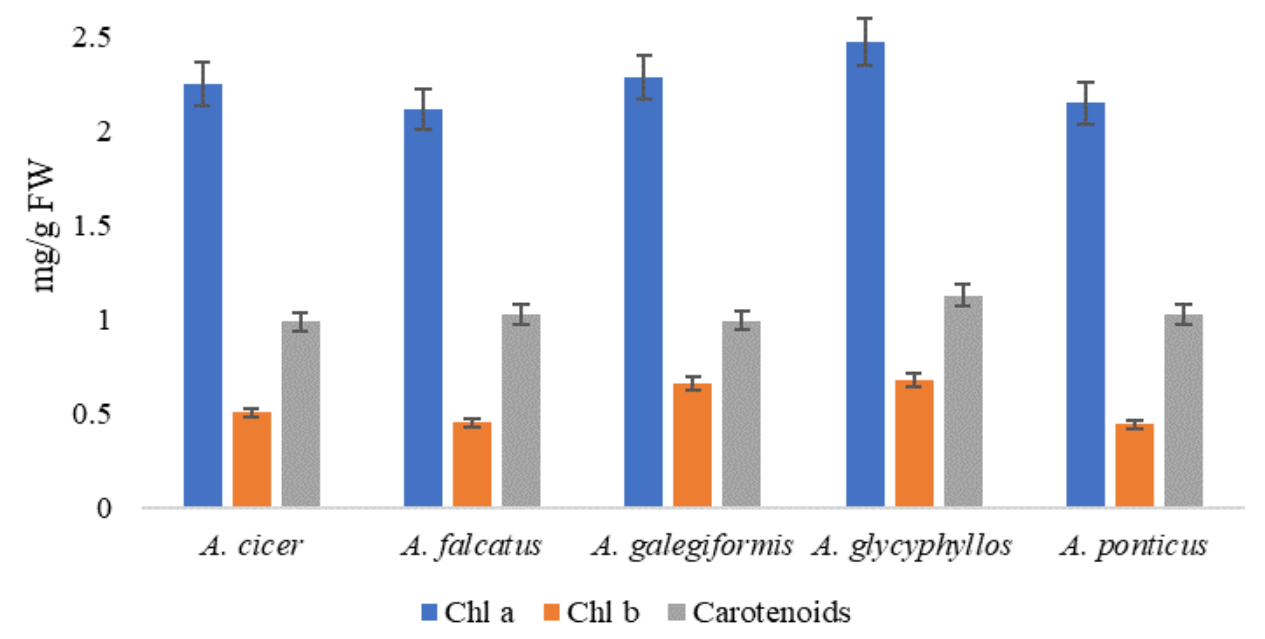

Figure 2. Content of photosynthetic pigments in the leaves of Astragalus species at the budding stage.

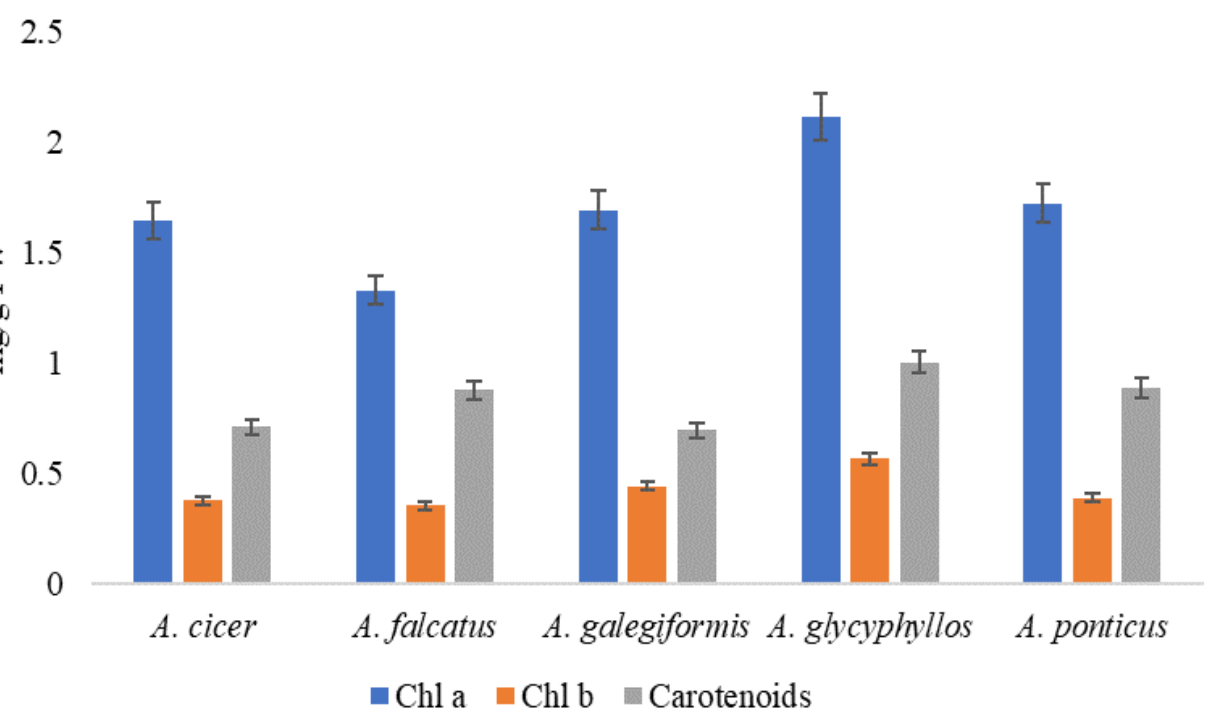

Figure 3. Content of photosynthetic pigments in the leaves of Astragalus species at the flowering stage.

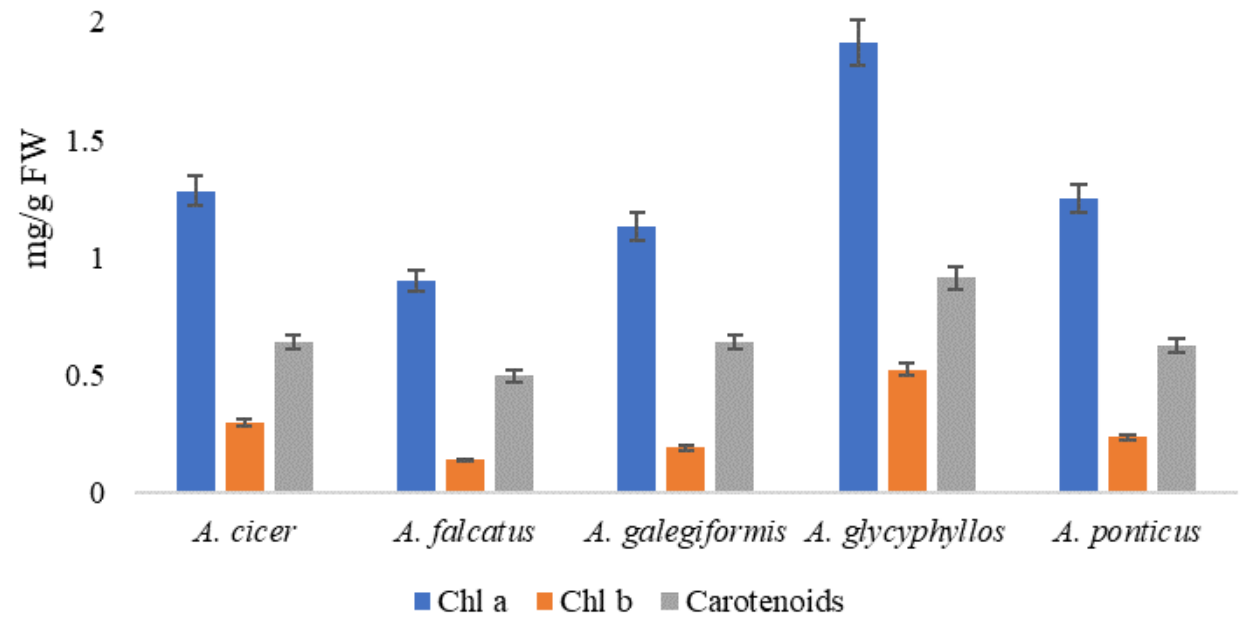

Figure 4. Content of photosynthetic pigments in the leaves of Astragalus species at the fruiting stage. 
is increasing (Filella et al., 2009). Gogoi \& Basumatary (2018) reported that ratio Chl $a$ / $\mathrm{Chl} b$ indicates the photosynthetic apparatus's development state and correlates with growth parameters. According to Anderson (1986), the regular ratios Chl $a / \mathrm{Chl} b$ for shade and light plants are 1.6-2.2 and 2.6-3.4, respectively.

The ratio Chl $a$ / Chl $b$ in the investigated Astragalus species at the budding stage was from 3.46 to 4.82 , the ratio of the sum of chlorophylls to carotenoids - from 2.51 to 2.96, and the ration of carotenoids to the sum of chlorophylls - from 0.34 to 0.40 (Fig. 5).

At the flowering stage, the sum of chlorophylls decreased comparing with budding stage (Fig. 6). The ratio Chl $a / \mathrm{Chl} b$ was 3.72-4.43, between the sum of chlorophylls and carotenoids - 1.92-3.08, and between carotenoids and sum of chlorophylls $-0.32-0.52$.

At the fruiting stage, the sum of chlorophylls was the lowest and varied from 1.039 to 2.436 (Fig. 7). The ratio of Chl $a / \mathrm{Chl} b$ was also lower and varied from 3.66 to 6.53 . The ratio of the sum of chlorophylls to carotenoids varied from 2.06 to 2.67, and the ratio of carotenoids to the sum of chlorophylls - from 0.31 to 0.48 .

The increment during budding, flowering and fruiting stage for A. cicer was $64.5 \mathrm{~cm}$ (84.14\%), $21.5 \mathrm{~cm}$ (21.98\%), and $1.2 \mathrm{~cm} \mathrm{(1.2 \% ),}$ respectively. For A. falcatus the increment was $64.4 \mathrm{~cm}(28.12 \%), 22.5 \mathrm{~cm}(21.69 \%)$, and $6.3 \mathrm{~cm}$ (5.73\%), respectively. For A. galegiformis it was $145.1 \mathrm{~cm}(91.02 \%), 20.7 \mathrm{~cm}(11.49 \%)$, and $12.6 \mathrm{~cm}$ (6.54\%), respectively. For A. glycyphyllos it was $85.2 \mathrm{~cm}(87.21 \%), 8.6 \mathrm{~cm}(8.09 \%)$, and $3.5 \mathrm{~cm}$ (3.18\%), respectively. And for A. ponticus it was $77.1 \mathrm{~cm}$ (81.85\%), $9.2 \mathrm{~cm}(8.89 \%)$ and $3.3 \mathrm{~cm}$ (3.09\%), respectively.

A very strong correlation between chlorophylls and carotenoid content in A. cicer has been identified (Table 1). Also, the content of phosphorus, ash, and increment of plants strongly correlated with photosynthetic pigments' content. Accumulation of calcium and phosphorus showed a negative correlation with pigments.

A similar strong correlation was also identified between pigments' content, accumulation of phosphorus, and increment of plants of A. falcatus (Table 2). A strong correlation was also found between calcium content and the ratio Chl $a / \mathrm{Chl} b$. The same relation was determined between ash content and Car / (Chl $a+\mathrm{Chl} b)$. A negative correlation was found between calcium content and the accumulation of pigments.

A strong correlation was found between the content of pigments, phosphorus, nitrogen, ash, and increment of A. galegiformis (Table 3). Similar strong correlation was also found between $(\mathrm{Chl} a+\mathrm{Chl} b) / \mathrm{Car}$ and content of phosphorus and nitrogen.

Like in a previous species, a strong correlation was found between photosynthetic pigments, phosphorus content, and increment of A. glycyphyllos (Table 4).

For A. ponticus it was found a strong correlation between phosphorus content and pigments, increment, and (Chl $a+\mathrm{Chl} b) / \mathrm{Car}$ ratio (Table 5). Ratio Car / (Chl $a+$ Chl b) correlated with nitrogen and ash. Calcium, nitrogen, and ash content demonstrated a negative correlation with pigments.

\section{Conclusions}

Thus, the accumulation of ash in the raw material of Astragalus species at the conditions of the NBG varied and depends on period of growth and certain species. Generally, this parameter for all investigated species was in the range of $3.12-5.22 \%$. The highest content of calcium has been noticed at the fruitage for all five species, whereas phosphorus content was maximal at the budding stage for four species excepting A. ponticus. Accumulation of nitrogen was different, and its maximal content for A. cicer, A. falcatus, and A. ponticus was fixed at the fruiting stage. Accumulation of photosynthetic pigments correlated with phosphorus content (a very strong correlation, $r=0.887-0.999$ ) and increment (strong and very strong correlations, $r=0.756-0.998)$ for all investigated species. Also, a very strong correlation was found between phosphorus content and chlorophylls ratio (Chl $a$ / Chl b). Considering the limited number of reviews about Astragalus photosynthetic content, obtained data could be beneficial, especially for studying the productivity of these plants. Obtained data demonstrated peculiarities of accumulation of ash and some of its components during vegetation that can be also useful at the cultivation of these plants in the Forest-Steppe of Ukraine. 
6

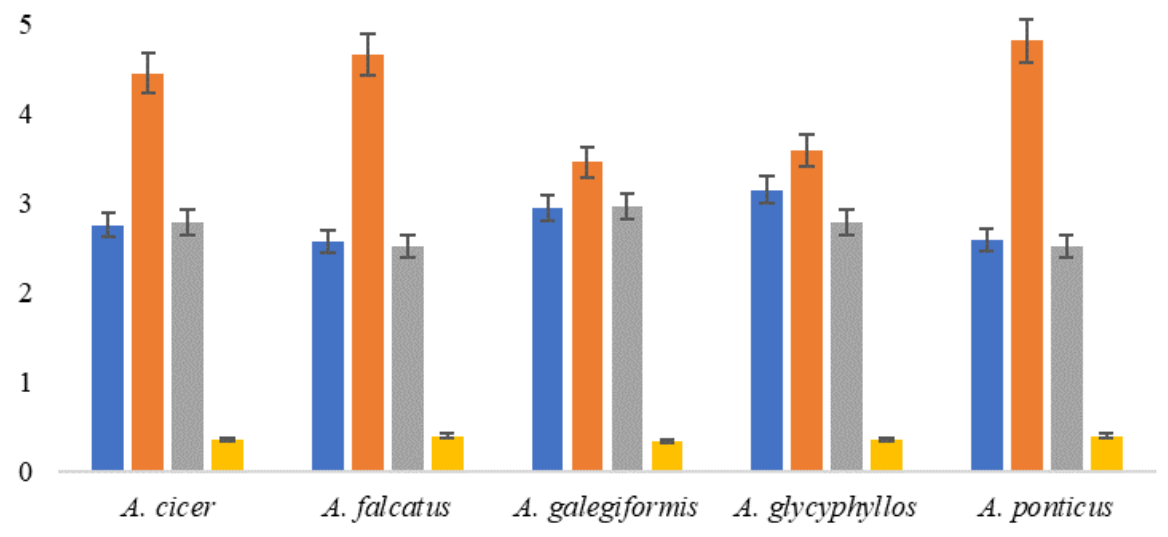

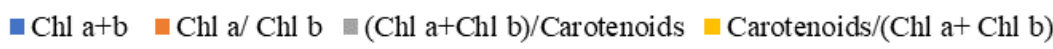

Figure 5. Relationship between photosynthetic pigments content at the budding stage.

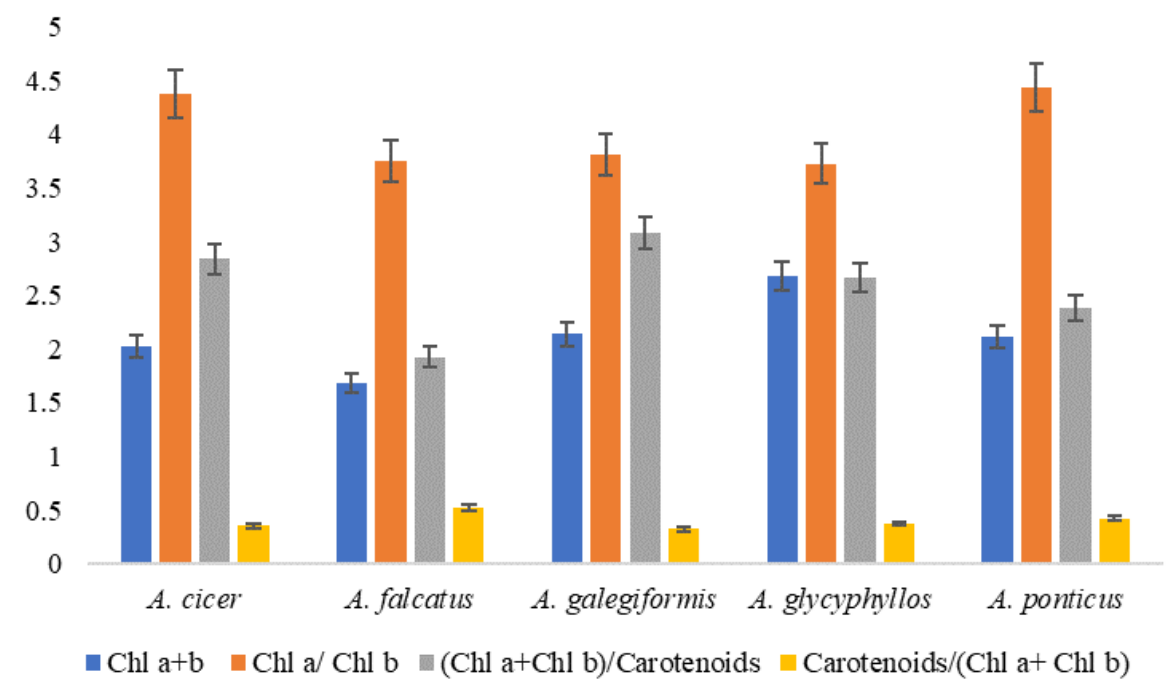

Figure 6. Relationship between photosynthetic pigments content at the flowering stage.

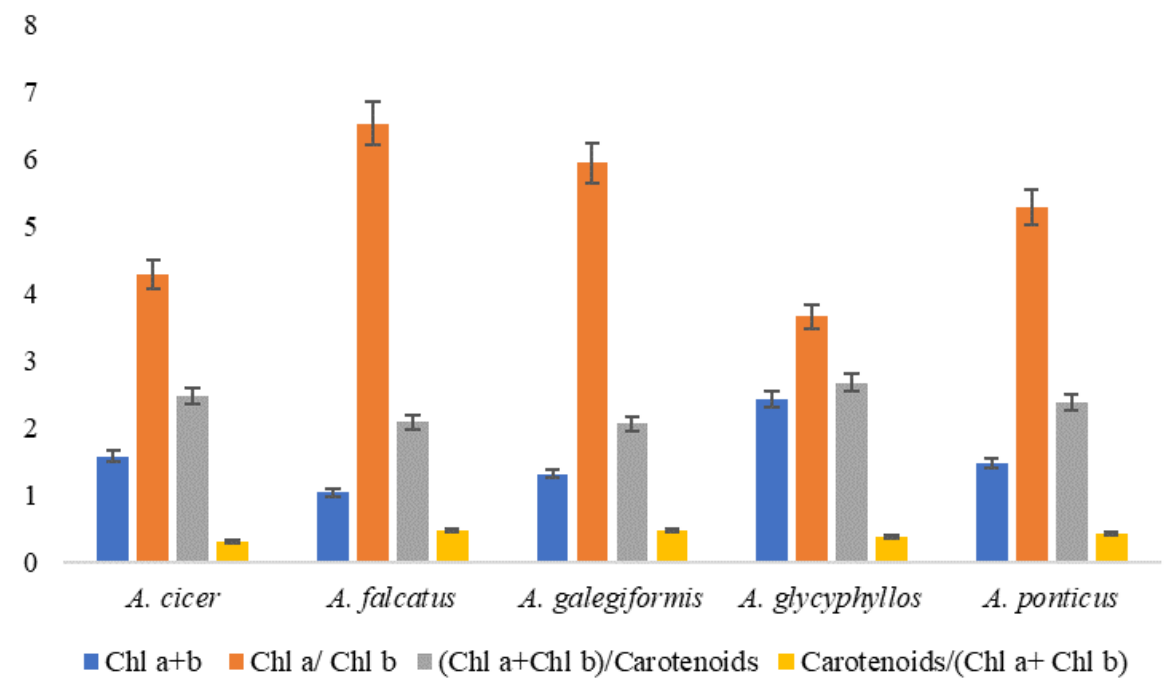

Figure 7. Relationship between photosynthetic pigments content at the fruiting stage. 
Table 1. Correlation of investigated parameters of Astragalus cicer.

\begin{tabular}{|c|c|c|c|c|c|c|c|c|c|c|}
\hline Parameter & Chl $a$ & Chl $b$ & Car & $\begin{array}{l}\text { Chl } a \text { / } \\
\text { Chl } b\end{array}$ & $\begin{array}{l}\mathrm{Chl}(a+b) / \\
\mathrm{Car}\end{array}$ & $\begin{array}{l}\mathrm{Car} / \\
\mathrm{Chl}(a+b)\end{array}$ & $\mathrm{Ca}$ & $\mathrm{P}$ & $\mathrm{N}$ & Ash \\
\hline Chl $b$ & 0.999 & 1 & & & & & & & & \\
\hline Car & 0.982 & 0.983 & 1 & & & & & & & \\
\hline $\mathrm{Chl} a / \mathrm{Chl} b$ & 0.977 & 0.976 & 0.920 & 1 & & & & & & \\
\hline $\mathrm{Chl}(a+b) / \mathrm{Car}$ & 0.702 & 0.701 & 0.557 & 0.838 & 1 & & & & & \\
\hline Car / Chl $(a+b)$ & 0.785 & 0.785 & 0.656 & 0.900 & 0.992 & 1 & & & & \\
\hline $\mathrm{Ca}$ & -0.913 & -0.913 & -0.821 & -0.979 & -0.932 & -0.970 & 1 & & & \\
\hline$P$ & 0.998 & 0.998 & 0.991 & 0.963 & 0.661 & 0.750 & -0.889 & 1 & & \\
\hline $\mathrm{N}$ & -0.945 & -0.944 & -0.867 & -0.993 & -0.897 & -0.945 & 0.996 & -0.925 & 1 & \\
\hline Ash & 0.979 & 0.979 & 0.924 & 0.999 & 0.833 & 0.895 & -0.977 & 0.966 & -0.992 & 1 \\
\hline Increment & 0.998 & 0.998 & 0.992 & 0.962 & 0.658 & 0.747 & -0.887 & 0.999 & -0.923 & 0.965 \\
\hline
\end{tabular}

Table 2. Correlation of investigated parameters of Astragalus falcatus.

\begin{tabular}{|c|c|c|c|c|c|c|c|c|c|c|}
\hline Parameter & Chl $a$ & Chl $b$ & Car & $\begin{array}{l}\text { Chl } a / \\
\text { Chl } b\end{array}$ & $\begin{array}{l}\mathrm{Chl}(a+b) / \\
\mathrm{Car}\end{array}$ & $\begin{array}{l}\mathrm{Car} / \\
\mathrm{Chl}(a+b)\end{array}$ & $\mathrm{Ca}$ & $\mathrm{P}$ & $\mathrm{N}$ & Ash \\
\hline Chl $b$ & 0.929 & 1 & & & & & & & & \\
\hline Car & 0.914 & 0.999 & 1 & & & & & & & \\
\hline $\mathrm{Chl} a / \mathrm{Chl} b$ & -0.524 & -0.801 & -0.825 & 1 & & & & & & \\
\hline $\mathrm{Chl}(a+b) / \mathrm{Car}$ & 0.803 & 0.527 & 0.492 & 0.087 & 1 & & & & & \\
\hline $\mathrm{Car} / \mathrm{Chl}(a+b)$ & -0.773 & -0.484 & -0.448 & -0.136 & -0.999 & 1 & & & & \\
\hline $\mathrm{Ca}$ & -0.840 & -0.981 & -0.988 & 0.902 & -0.352 & 0.304 & 1 & & & \\
\hline $\mathrm{P}$ & 0.998 & 0.999 & 0.991 & 0.963 & 0.661 & 0.750 & -0.889 & 1 & & \\
\hline $\mathrm{N}$ & -0.991 & -0.971 & -0.960 & 0.634 & -0.716 & 0.679 & 0.905 & -0.953 & 1 & \\
\hline Ash & -0.915 & -0.702 & -0.673 & 0.136 & -0.975 & 0.963 & 0.550 & -0.655 & 0.853 & 1 \\
\hline Increment & 0.997 & 0.896 & 0.878 & -0.453 & 0.849 & -0.821 & -0.793 & 0.866 & -0.977 & -0.945 \\
\hline
\end{tabular}

Table 3. Correlation of investigated parameters of Astragalus galegiformis.

\begin{tabular}{|c|c|c|c|c|c|c|c|c|c|c|}
\hline Parameter & Chl $a$ & Chl $b$ & Car & $\begin{array}{l}\text { Chl } a \text { / } \\
\text { Chl } b\end{array}$ & $\begin{array}{l}\mathrm{Chl}(a+b) / \\
\mathrm{Car}\end{array}$ & $\begin{array}{l}\text { Car / } \\
\text { Chl }(a+b)\end{array}$ & $\mathrm{Ca}$ & $\mathrm{P}$ & $\mathrm{N}$ & Ash \\
\hline Chl $b$ & 0.998 & 1 & & & & & & & & \\
\hline Car & 0.934 & 0.909 & 1 & & & & & & & \\
\hline $\mathrm{Chl} a / \mathrm{Chl} b$ & -0.917 & -0.940 & -0.714 & 1 & & & & & & \\
\hline $\mathrm{Chl}(a+b) / \mathrm{Car}$ & 0.798 & 0.834 & 0.529 & -0.972 & 1 & & & & & \\
\hline $\mathrm{Car} / \mathrm{Chl}(a+b)$ & -0.793 & -0.830 & -0.523 & 0.970 & -0.999 & 1 & & & & \\
\hline $\mathrm{Ca}$ & -0.997 & -0.991 & -0.956 & 0.887 & -0.753 & 0.749 & 1 & & & \\
\hline $\mathrm{P}$ & 0.995 & 0.999 & 0.892 & -0.953 & 0.855 & -0.852 & -0.985 & 1 & & \\
\hline $\mathrm{N}$ & 0.963 & 0.978 & 0.803 & -0.990 & 0.931 & -0.928 & -0.942 & 0.986 & 1 & \\
\hline Ash & 0.999 & 0.997 & 0.940 & -0.910 & 0.786 & -0.782 & -0.998 & 0.992 & 0.958 & 1 \\
\hline Increment & 0.899 & 0.870 & 0.996 & -0.651 & 0.453 & -0.447 & -0.928 & 0.849 & 0.748 & 0.907 \\
\hline
\end{tabular}


Table 4. Correlation of investigated parameters of Astragalus glycyphyllos.

\begin{tabular}{|c|c|c|c|c|c|c|c|c|c|c|}
\hline Parameter & Chl $a$ & Chl $b$ & Car & $\begin{array}{l}\text { Chl } a \text { / } \\
\text { Chl } b\end{array}$ & $\begin{array}{l}\mathrm{Chl}(a+b) / \\
\mathrm{Car}\end{array}$ & $\begin{array}{l}\mathrm{Car} / \\
\mathrm{Chl}(a+b)\end{array}$ & $\mathrm{Ca}$ & $\mathrm{P}$ & $\mathrm{N}$ & Ash \\
\hline $\mathrm{Chl} b$ & 0.997 & 1 & & & & & & & & \\
\hline Car & 0.997 & 0.989 & 1 & & & & & & & \\
\hline Chl $a /$ Chl $b$ & -0.672 & -0.723 & -0.614 & 1 & & & & & & \\
\hline $\mathrm{Chl}(a+b) / \mathrm{Car}$ & 0.937 & 0.960 & 0.909 & -0.887 & 1 & & & & & \\
\hline $\mathrm{Car} / \mathrm{Chl}(a+b)$ & -0.956 & -0.971 & -0.996 & 0.537 & -0.866 & 1 & & & & \\
\hline $\mathrm{Ca}$ & -0.976 & -0.989 & -0.956 & 0.818 & -0.991 & 0.925 & 1 & & & \\
\hline $\mathrm{P}$ & 0.989 & 0.997 & 0.976 & -0.772 & 0.978 & -0.951 & -0.997 & 1 & & \\
\hline $\mathrm{N}$ & 0.136 & 0.064 & 0.211 & 0.642 & -0.217 & -0.300 & 0.085 & -0.009 & 1 & \\
\hline Ash & -0.127 & -0.056 & -0.202 & -0.648 & 0.225 & 0.292 & -0.093 & 0.017 & -0.999 & 1 \\
\hline Increment & 0.955 & 0.974 & 0.930 & -0.860 & 0.998 & -0.892 & -0.997 & 0.988 & -0.162 & 0.170 \\
\hline
\end{tabular}

Table 5. Correlation of investigated parameters of Astragalus ponticus.

\begin{tabular}{|c|c|c|c|c|c|c|c|c|c|c|}
\hline Parameter & Chl $a$ & Chl $b$ & Car & $\begin{array}{l}\text { Chl } a \text { / } \\
\text { Chl } b\end{array}$ & $\begin{array}{l}\mathrm{Chl}(a+b) / \\
\mathrm{Car}\end{array}$ & $\begin{array}{l}\mathrm{Car} / \\
\mathrm{Chl}(a+b)\end{array}$ & $\mathrm{Ca}$ & $\mathrm{P}$ & $\mathrm{N}$ & Ash \\
\hline Chl $b$ & 0.974 & 1 & & & & & & & & \\
\hline Car & 0.990 & 0.996 & 1 & & & & & & & \\
\hline $\mathrm{Chl} a / \mathrm{Chl} b$ & -0.575 & -0.744 & -0.683 & 1 & & & & & & \\
\hline $\operatorname{Chl}(a+b) / \mathrm{Car}$ & 0.847 & 0.707 & 0.766 & -0.057 & 1 & & & & & \\
\hline $\mathrm{Car} / \mathrm{Chl}(a+b)$ & -0.848 & -0.707 & -0.766 & 0.053 & -1 & 1 & & & & \\
\hline $\mathrm{Ca}$ & -0.991 & -0.996 & -0.999 & 0.679 & -0.769 & 0.769 & 1 & & & \\
\hline$P$ & 0.968 & 0.887 & 0.924 & -0.352 & 0.953 & -0.953 & -0.926 & 1 & & \\
\hline $\mathrm{N}$ & -0.996 & -0.953 & -0.976 & 0.507 & -0.888 & 0.888 & 0.977 & -0.985 & 1 & \\
\hline Ash & -0.999 & -0.976 & -0.991 & 0.581 & -0.844 & 0.844 & 0.992 & -0.966 & 0.996 & 1 \\
\hline Increment & 0.883 & 0.756 & 0.810 & -0.125 & 0.997 & -0.997 & -0.813 & 0.972 & -0.918 & -0.880 \\
\hline
\end{tabular}

\section{References}

Adigüzel, A., Sökmen, M., Özkan, H., Ağar, G., Güllüce, M., \& Şahin, F. (2009). In vitro antimicrobial and antioxidant activities of methanol and hexane extract of Astragalus species growing in the Eastern Anatolia region of Turkey. Turkish journal of Biology, 33, 65-71. https://doi.org/10.3906/biy-0805-1

Alrumman, S. A., Moustafa, M. F. M., \& Alamri, S. A. (2012). Antibacterial and anti-fungal investigation of Astragalus atropilosulus subsp. abyssinicus. African Journal of Microbiology Research, 6(34), 6365-6369.

Amiri, M. S., Joharchi, M. R., Nadaf, M., \& Nasseh, Y. (2020). Ethnobotanical knowledge of Astragalus spp.: The world's largest genus of vascular plants. Avicenna Journal of Phytomedicine, 10(2), 128-142.
Anderson, J. M. (1986). Photoregulation of the composition function and structure of thylakoid membranes. Annual Review of Plant Physiology, 37, 93-136. https://doi.org/10.1146/annurev. pp.37.060186.000521

Asharya, S. N., Kastelic, J. P., Beauchemin, K. A., \& Messenger, D. F. (2006). A review of research progress on cicer milkvetch (Astragalus cicer L.). Canadian Journal of Plant Science, 86, 49-62. https://doi.org/10.4141/ P04-174

Auyeung, K. K., Han, Q.-B., \& Ko, K. J. (2016). Astragalus membranaceus: A review of its protection against inflammation and gastrointestinal cancers. The American Journal of Chinese Medicine, 44(1), 1-22. https://doi. org/10.1142/S0192415X16500014 
Babich, O., Prosekov, A., Zaushintsena, A., Sukhikh, A., Dyshlyuk, L., \& Ivanova, S. (2019). Identification and quantification of phenolic compounds of Western Siberia Astragalus danicus in different regions. Heliyon, 5, e02245. https:// doi.org/10.1016/j.heliyon.2019.e02245

Berezutskii, M. A., Yakubova, L. K., Durnova, N. A., Romanteeva, Y. V., Belonogova, Y. V., Komarova, E. E., Sheremet'eva, A. S. (2020). Pharmacological properties of preparations based on Astragalus extract (review). Pharmaceutical Chemistry Journal, 54(4), 372-374. https://doi.org/10.1007/s11094-020-02206-x

Bondarchuk, O. P., \& Rakhmetov, D. B. (2016). Ontomorphogenesis of plant of the genus Astragalus L. in conditions of introduction in the Right-Bank of Forest-Steppe of Ukraine. Plant Introduction, 70(2), 45-51. https://doi. org/10.5281/zenodo.2355177

Bondarchuk, O. P., \& Rakhmetov, D. B. (2017). Productivity of plants of the genus Astragalus L. species in conditions of introduction into Right-Bank of Forest-Steppe of Ukraine. Plant Introduction, 76(4), 11-19. https://doi. org/10.5281/zenodo.2327280

Chasemian-Yadegari, J., Hamedeyazdan, S., Nazemiyeh, H., \& Fathiazad, F. (2019). Evaluation of phytochemical, antioxidant and antibacterial activity on Astragalus chrysostachis Boiss. roots. Iranian Journal of Pharmaceutical Research, 18(4), 1902-1911. https://doi.org/10.22037/ ijpr.2019.1100855

Filella, I., Porcar-Castell, A., Munne-Bosch, S., Back, J., Garbulsky, M. F., \& Peñuelas, J. (2009). PRI assessment of long-termchanges in carotenoids/chlorophyll ratio and shortterm changes in the de-epoxidation state of the xanthophyll cycle. International Journal of Remote Sensing, 30(17), 4443-4455. https://doi. org/10.1080/01431160802575661

Fu, J., Wang, Z., Huang, L., Zheng, S., Wang, D., Chen, S., Zhang, H., \& Yang, S. (2014). Review of the botanical characteristics, phytochemistry, and pharmacology of Astragalus membranaceus (Huangqi). Phytotherapy Research, 28(9), 12751283. https://doi.org/10.1002/ptr.5188

Godočiková, L., Ivanišová, E., Noguera-Artiaga, L., Carbonell-Barrachina, A. A., Kačaniová, M. (2019). Biological activity, antioxidant capacity and volatile profile of enriched Slovak chocolates. Journal of Food and Nutritional Research, 58(3), 283-293.

Gogoi, M., \& Basumatary, M. (2018). Estimation of the chlorophyll concentration in seven Citrus species of Kokrajhar district, BTAD, Assam, India. Tropical Plant Research, 5(1), 83-87. https://doi. org/10.22271/tpr.2018.v5.11.012
Guo, M.-F., Dai, Y.-J., Gao, J.-R., \& Chen, P.-J. (2020). Uncovering the mechanism of Astragalus membranaceus in the treatment of diabetic nephropathy based on network pharmacology. Journal of Diabetes Research, 2020, 5947304. https://doi.org/10.1155/2020/5947304

Guo, Z., Lou, Y., Kong, M., Luo, Q., Liu, Z., \& Wu, J. (2019). A systematic review of phytochemistry, pharmacology and pharmacokinetics on Astragali radix: Implications for astragali radix as a personalized medicine. International Journal of Molecular Sciences, 20, 1463. https://doi. org/10.3390/ijms20061463

Hrytsajenko, Z. M., Hrytsajenko, V. P., \& Karpenko, V. P. (2003). Methods of biological and agrochemical investigations of plants and soils. Kyiv: Nichlava. (In Ukrainian)

Ilçim, A., \& Behçet, L. (2016). Astragalus topalanense (Fabaceae), a new species from Turkey. Turkish Journal of Botany, 40, 74-80. https://doi. org/10.3906/bot-1409-22

Jaradat, N. A., Al-Masri, M., Zaid, A. N., Eid, A. M., Saleh, A. M., Zer, A. F. A., Romi, I. M., \& Hussein, A. M. A. (2017). Preliminary phytochemical screening and in-vitro evaluation of antioxidant and antimicrobial activities for Astragalus pelecinus from Palestine. Journal of Materials and Environmental Sciences, 8, 4, 1492-1497.

Kalnytskyi, B. D. (1997). Methods of biochemical analyse. Borovsk: VNIIFBiP. (In Russian)

Keskin, C. \& Kacar, S. (2013). Fatty acid composition of root and shoot samples of some Astragalus L. (Fabaceae) taxa growing in the east and southeast of Turkey. Turkish Journal of Biology, 37, 122-128. https://doi.org/10.3906/biy-1203-2

Kumleh, A. A., Asgarpanah, J., \& Ziarati, P. (2016). Chemical composition and nutritive value of Astragalus podolobus seeds growing wild in South of Iran. Biomedical \& Pharmacology Journal, 9(3), 1117-1125. https://doi.org/10.13005/bpj/1058

Li, T., Jiang, J., \& Liu, J. (2019a). Spectroscopic determination of leaf chlorophyll content and color for genetic selection on Sassafras tzumu. Plant Methods, 15, 1-13. https://doi.org/10.1186/ s13007-019-0458-0

Li, Z. X., Zhao, G. D., Xiong, W., Linghu, K. G., Ma, Q. S., Cheang, W. S., Yu, H., \& Wang, Y. (2019b). Immunomodulatory effect of a new whole ingredients extract from Astragalus: a combined evaluation on chemistry and pharmacology. Chinese Medicine, 14, 1-12. https://doi.org/10.1186/s13020-019-0234-0

Lichtenthaler, H. K. (1987). Chlorophylls and carotenoids: Pigments of photosynthetic membranes. Methods in Enzymology, 148, 350-382. http://dx.doi.org/10.1016/0076-6879(87)48036-1 
Lysiuk, R., \& Darmohray, R. (2016). Pharmacology and ethnomedicine of the genus Astragalus. International Journal of Pharmacology, Phytochemistry and Ethnomedicine, 3, 46-53. https://doi. org/10.18052/www.scipress.com/IJPPE.3.46

Musijenko, M. M., Parshikova, T. V., \& Slavnyi, P. S. (2001). Spectrophotometric methods in practice of plant physiology, biochemistry and ecology. Kyiv: Phytosociocentr. (In Ukrainian)

Prochnow, A., Heiermann, M., Plöchl, M., Amon, T., Hobbs, P. J. (2009). Bioenergy from permanent grassland - a review: 2. Combustion. Bioresource Technology, 100, 4945-4954. https:// doi.org/10.1016/j.biortech.2009.05.069

Rakhmetov, D., Bondarchuk, O., Vergun, O., \& Fishchenko, V. (2018). Biochemical characteristics of above-ground phytomass of plants of the genus Astragalus L. in the Right Bank of Forest-Steppe of Ukraine. Science Rise: Biological Sciences, 3(12), 48-52. https://doi. org/10.15587/2519-8025.2018.135852

Sarraj-Laabidi, A., Lacaille-Dubois, M. A., \& Semmar, N. (2018). Structural organization of cycloartane-based saponins in the genus Astragalus (Fabaceae). Phytochemistry Reviews, 17(2), 431-452. https://doi.org/10.1007/s11101017-9541-1

Shojaii, A., Mataghinejad, M., Norouzi, S., Motevalian, M. (2013). Evaluation of antiinflammatory and analgesic activity of the extract and fractions of Astragalus hamosus in animal models. Iranian Journal of Pharmaceutical Research, 14(1), 263-269. https://dx.doi.org/10.22037/ ijpr.2015.1620
Vergun, O. M., Rakhmetov, D. B., Rakhmetova, S. O., Fishchenko, V.V. (2019). Distribution of nutrients in different organs of plants of Miscanthus Anderss. genotypes. Plant Introduction, 81, 75-81. https://doi.org/10.5281/zenodo.2650469

Vergun, O. M., Shymanska, O. V., \& Rakhmetov, D. B. (2012). Biochemical characteristic of Galega L. species in Right-Bank of Forest-Steppe of Ukraine. Odesa National University Harold, 17(3), 43-50.

Wang, J., Jia, J., Song, L., Gong, X., Xu, J., Yang, M., \& Li, M. (2019). Extraction, structure, and pharmacological activities of Astragalus polysaccharides. Applied Sciences, 9, 122. https:// doi.org/10.3390/app9010122

Yermakov, A. I., Arasimovich, V. V., SmirnovaIkonnikova, M. I., \& Yarosh, N. P. (1972). Methods of biochemical investigations of plants. Leningrad: Kolos. (In Russian)

Zhang, Z. Y. (2013). Characterization of major flavonoids, triterpenoid, dipeptide and their metabolites in rat urine after oral administration of radix astragali decoction. Journal of Analytical Chemistry, 68(8), 787-792. https://doi. org/10.1134/S1061934813080145

Zheng, Y., Ren, W., Zhang, L., Zhang, Y., Liu, D., \& Liu, Y. (2020). A review of the pharmacological action of Astragalus polysaccharides. Frontiers in Pharmacology, 11, 349. https://doi.org/10.3389/ fphar.2020.00349

Zlatev, Z., \& Lidon, F. C. (2012). An overview on drought induced changes in plant growth, water relations and photosynthesis. Emirate Journal of Food and Agriculture, 24(1), 57-72. https://dx.doi. org/10.9755/ejfa.v24i1.10599

\section{Накопичення золи та фотосинтетичних пігментів у рослинній сировині видів роду Astragalus}

Олександр Бондарчук *, Олена Вергун, Оксана Шиманська, Валентина Фіщенко, Джамал Рахметов

Національний ботанічний сад імені М.М. Гришка НАН України, вул. Тимірязєвська, 1, м. Київ, 01014, Україна; * bondbiolog@gmail.com

Досліджено п'ять видів роду Astragalus (A. cicer, A. falcatus, A. galegiformis, A. glycyphyllos та A. ponticus) 3 відділу культурної флори Національного ботанічного саду імені М.М. Гришка НАН України. Рослинну сировину для досліджень відбирали у період бутонізації, квітування та плодоношення. Після чого, визначали у ній вміст золи, кальцію, фосфору, азоту та фотосинтетичних пігментів.

Вміст золи у фітосировині варіював від 3,12 до 5,22 \%, кальцію - від 0,31 до 0,91 \%, фосфору - від 0,07 до 0,14\%, азоту - від 1,93 до 2,48 \% залежно від фази розвитку. Вміст хлорофілу а становив від 0,901 до 2,475 мг/г, хлорофілу $b$ - від 0,190 до 0,676 мг/г, а каротиноїдів - від 0,496 до 1,129 мг/г. 
Таким чином, накопичення золи та їі компонентів у фітосировині досліджених видів варіювало і залежало від періоду розвитку та видових особливостей. Вміст фотосинтетичних пігментів корелював із вмістом фосфору $(r=0,887-0,999)$ та з приростом рослин $(r=0,756-0,998)$ для усіх досліджених видів. Отримані відомості можуть бути використані для дослідження продуктивності цих рослин та під час їх культивування.

Ключові слова: Astragalus, рослинна сировина, вміст золи, фотосинтетичні пігменти, кореляція 